\title{
DISTRIBUSI SPASIAL KEPADATAN PENDUDUK DAN JUMLAH KEJADIAN COVID-19 MINGGUAN DI KABUPATEN MAGELANG
}

\author{
Sidiq Purwoko ${ }^{1,2^{\star}}$, Widya Hary Cahyati ${ }^{1}$, Zainuddin $^{2}$, Ina Kusrini ${ }^{2}$ \\ ('Universitas Negeri Semarang, ${ }^{2}$ Balai Litbangkes Magelang)
}

\begin{abstract}
Covid-19 is a deadly infectious disease with a fast transmission rate in a short time. The incidence of Covid-19 is caused by various factors, one of which is the demographic factor of an area. In 2020, positive Confirmation Cases in Magelang Regency were ranked the second highest in Central Java Province with 4418 cases. . This type of quantitative descriptive research with an ecological study design uses a spatial approach with a subdistrict analysis unit. The sample in the study was all new cases of positive confirmation of Covid-19 in the next episode in December 2020 by utilizing secondary data on the official website of the Magelang Regency government. The analysis used is correlation and regression analysis between variables, while the mapping of cases uses an overlay technique using QGIS 3.10 software. The results showed a strong relationship between variables by 54\% and from the results of spatial mapping showed the highest cases occurred in the third week with 790 cases and the two highest sub-districts were sub-districts with population density above 1900 people/km2, namely Mertoyudan District and Mungkid District. The conclusion of the study is that the distribution of the Covid-19 television program in Magelang Regency in December 2020 is influenced by the level of population density. Research advice is that stakeholders' attention is needed for areas with high density levels in handling Covid-19 in Magelang Regency
\end{abstract}

Keywords: Population density ; Mapping Covid-19 ; Spatial Analysis

\begin{abstract}
Abstrak
Covid-19 adalah salah satu penyakit menular mematikan dengan laju penularan yang cepat dalam waktu yang singkat. Kejadian Covid-19 di sebabkan oleh berbagai faktor, salah satunya adalah faktor demografi suatu wilayah. Pada tahun 2020, Kasus Konfirmasi positif di Kabupaten Magelang menempati peringkat kedua tertinggi di Provinsi Jawa Tengah dengan 4418 kasus.Tujuan penelitian ini adalah mengetahui hubungan antara variabel kepadatan penduduk dan kejadian Covid-19 di Kabupaten Magelang dan memetakan tingkat kejadian mingguan Covid-19 dengan pendekatan Spasial. Jenis penelitian adalah deskriptif kuantitatif dengan desain studi ekologi menggunakan pendekatan spasial dengan unit analisis kecamatan. Sampel dalam penelitian adalah semua kasus baru konfirmasi positif Covid-19 pada dalam tingkat mingguan pada Bulan Desember 2020 dengan memanfaatkan data sekunder pada laman resmi pemerintah Kabupaten Magelang. analisis yang digunakan adalah analisis korelasi dan regresi antar variabel sedangkan pemetaan sebaran kasus menggunakan teknik overlay menggunakan perangkat lunak QGIS 3.10. Hasil penelitian menunjukkan adanya hubungan yang kuat antar variabel sebesar $54 \%$ dan dari hasil pemetaan spasial menunjukkan kasus tertinggi terjadi pada minggu ke tiga dengan 790 kasus dan dua kecamatan tertinggi kasus adalah kecamatan dengan kepadatan penduduk tinggi diatas $1900 \mathrm{jiwa} / \mathrm{km}^{2}$ yaitu Kecamatan Mertoyudan dan Kecamatan Mungkid. Kesimpulan penelitian adalah persebaran kasus mingguan Covid-19 Kabupaten Magelang pada Bulan Desember 2020 dipengaruhi oleh tingkat kepadatan penduduk. Saran Penelitian adalah diperlukan perhatian pemangku kepentingan untuk wilayah dengan tingkat kepadatan tinggi dalam penanganan Covid-19 di Kabupaten Magelang.
\end{abstract}

Keywords: Kepadatan Penduduk ; Pemetaan Covid-19 ; Analisis Spasial 


\section{PENDAHULUAN}

Covid-19 adalah penyakit infeksius yang disebabkan oleh virus Severe acute respiratory syndrome coronavirus 2 (SARS-CoV-2) ${ }^{1}$. Pada awalnya virus ini menginfeksi hewan, dan penularan yang terjadi antara hewan dengan hewan, namun seiring waktu virus ini di sebut sebagai virus zoonotik karena kemampuannya untuk bertransmisi dari hewan ke manusia ${ }^{2}$. Penyebarannya yang semakin cepat dan hampir seluruh negara di dunia mengalami peningkatan kasus sehingga membuat badan kesehatan dunia WHO (World Health Organization) menetapkan status pandemi pada akhir Januari $2020^{1}$. Kondisi tersebut terjadi karena SARS-Cov-2 mampu bertranmisi dengan cepat antara manusia ${ }^{3}$. Sampai pertengahan tahun 2021 virus Covid-19 telah tersebar di 216 negara di dunia, dari data yang di rilis pada laman dasboard WHO, virus ini telah menjangkiti 175.306 .598 penduduk bumi, dengan 3.792.777 kematian $(2,16 \%)^{4}$.

Indonesia merilis data bahwa virus Covid-19 telah menyebar ke 34 Provinsi, sampai pertengahan tahun 2021 telah terdapat 1.911 .358 kasus konfirmasi positif dengan 52.879 angka kematian $(2,76 \%)^{5}$. Provinsi Jawa Tengah sebagai salah satu provinsi di Indonesia, berada di peringkat ketiga provinsi dengan kasus tertinggi. Data Info grafis yang di rilis Badan Penanggulangan Bencana Daerah (BPBD) Kabupaten Magelang menunjukkan pada tahun 2020 kasus konfirmasi positif tercatat sejumlah 6001 Kasus dengan tren lonjakan meningkat dari bulan ke bulan yang di mulai pada Maret 2020 dengan penambahan kematian 62 Jiwa di bulan Desember sehingga di tahun tersebut Kabupaten Magelang mencatat kematian total 145 Jiwa. Bulan Desember 2020 adalah bulan tertinggi kasus dengan 3151 kasus konfirmasi positif Covid-19 dimana sebelumnya di bulan November tercatata 1819 kasus atau terjadi peningkatan $73 \%$ dari bulan sebelumnya. Kasus Covid-19 telah terjadi merata di 21 Kecamatan di Kabupaten Magelang dengan jumlah kasus yang variatif dan berbeda-beda. Peningkatan kejadian penyakit menular di pengaruhi oleh kondisi lingkungan, perilaku penduduk, sosio-ekonomi hingga kepadatan penduduknya ${ }^{6}$.

Peningkatan jumlah penduduk dalam sebuah wilayah merupakan akibat dari pertumbuhan ekonomi yang terus berkembang, kondisi tersebut berimbas pada penambahan jumlah pemukiman dan akan meningkatkan naiknya tingkat kepadatan penduduk ${ }^{7}$. Kepadatan penduduk di sinyalir memiliki andil dalam peningkatan kasus Covid19 di Indonesia, hal ini terkait dengan kenyataan bahwa wilayah perkotaan yang memiliki kepadatan lebih tinggi di banding wilayah perdesaan memiliki angka transmisi yang lebih cepat dengan lingkaran penularan yang lebih kompleks ${ }^{8}$. Variabel kepadatan penduduk menjadi variabel yang mempengaruhi penyebaran Covid-19 di negara bagian Carolina Selatan ${ }^{8}$. Penelitian tersebut menjelaskan bahwa tempat tinggal padat di daerah perkotaan dapat mempercepatpenularan SAR-CoV-2, yang mengarah ke jumlah total kasus terkonfirmasi COVID-19 yang lebih tinggi. Penelitian lain di Kota Manado provinsi Sulawesi 
Utara menunjukkan bahwa kecamatan di Kota Manado yang memiliki kepadatan penduduk tinggi memiliki angka kejadian Covid-19 yang tinggi ${ }^{9}$. Penelitian lainnya di Kota Semarang menjelaskan bahwa sebagian besar wilayah kecamatan di Kota Semarang menunjukkan keterkaitan antara kepadatan penduduk dengan kejadian COVID-19 di Kota Semarang tahun $2020^{10}$. Namun penelitian lain yang dilakukan di Kabupaten Badung Provinsi Bali menjelaskan bahwa terdapat hubungan yang sangat lemah antar variabel kejadian Covid-19 dengan kepadatan penduduk yaitu 1,7 \%, kondisi tersebut di karenakan kejadaian Covid-19 di Kabupaten Badung hanya meningkat pada pada kecamatan yang memiliki kepadatan penduduk sedang ${ }^{11}$. Kondisi tersebut menarik untuk dilakukan penelitian mengingat Kabupaten Magelang adalah Kabupaten dengan karakteristik wilayah beragam dari sisi kepadatan penduduk serta lokasinya berada di antara dua provinsi yaitu Provinsi Jawa Tengah dan Provinsi DI Yogyakarta.

Pemetaan terhadap distribusi kejadian Covid-19 dengan memanfaatkan pola spasial penting dilakukan untuk membantu pemangku kepentingan terkait dalam memahami dengan cepat pola sebaran Covid-19 bila di lihat dari sisi spasial ${ }^{12}$. Hal ini menarik untuk di lakukan kajian dan penelitian mengingat Kabupaten Magelang memiliki karakter wilayah yang beragam dari sisi kepadatan penduduk dan wilayahnya berada di antara dua provinsi yaitu Provinsi Jawa Tengah dan Provinsi DI Yogyakarta dan menjadi wilayah yang sering di lalui masyarakat dalam beraktifitas di kedua provinsi tersebut. Tujuan dari penelitian ini adalah mengetahui hubungan antara variabel kepadatan penduduk tingkat kecamatan di Kabupaten Magelang dengan kasus Covid-19 dan memetakan tingkat kejadian pada Bulan Desember 2020 dimana bulan tersebut adalah bulan tertinggi kejadian Covid-19 selama tahun 2020 .

Pemetaan ini juga dapat membantu menambah informasi kepada masyarakat dalam mencegah penyebaran penyakit serta dapat membantu pemangku kebijakan setempat agar dapat memberikan gambaran visualisasi sebaran kejadian Covid-19 dalam upaya peningkatan sistem perencanaan, evaluasi, serta pengambilan keputusan dalam penanggulangan Kejadaian pandemi Covid-19 di Kabupaten Magelang.

\section{METODE PENELITIAN}

Jenis penelitian adalah deskriptif kuantitatif dengan desain studi ekologi menggunakan pendekatan spasial. Studi ekologi adalah studi epidemiologi dengan populasi sebagai unit analisnya yang memiliki tujuan untuk mendeskripsikan hubungan antara variabel terikat dan tidak terikat dimana variabel terikatnya adalah kasus konfirmasi positif Covid-19 baru dan variabel tidak terikatnya adalah kepadatan penduduk di 21 kecamatan. Objek dalam penelitian ini adalah kepadatan penduduk dan tingkat kejadian Covid-19 di Kabupaten Magelang. Data yang digunakan adalah data sekunder yang di dapat dari kanal resmi info Covid-19 pemerintah Kabupaten Magelang dan data kepadatan penduduk Kabupaten 
magelang yang dirilis BPS Kabupaten Magelang tahun 2020. Teknik analsis data yang digunakan untuk melihat hubungan dan pengaruh adalah analisis korelasi dan regresi linier. Sedang proses pemetaan kasus dan tingkat kejadian Covid-19 dengan menggunakan software QGIS 3.10 .

Beberapa data tersebut akan di konversikan menjadi data spasial dan di analisis menggunakan teknik overlay atau teknik tumpang susun dengan menggunakan perangkat lunak QGIS 3.10 guna menghasilkan unit pemetaan yang baru dan akan di interpretasikan pola hubungan antara variabel terikat dan varibel bebasnya. Data yang digunakan dalam penelitian ini adalah data kepadatan penduduk yang di dapat dari Biro Pusat Statistik (BPS) Kabupaten Magelang ${ }^{13}$. Serta data harian kasus Covid-19 yang bersumber dari kanal resmi Covid-19 Kabupaten Magelang, sedangkan peta dasar wilayah di dapat dari kanal Badan Informasi Geopasial (BIG). Proses analisis kejadian menggunakan perangkat lunak Sistem Informasi Geografis (SIG) yaitu Quantum GIS (QGIS) versi 3.10 dan digunakan untuk memetakan kejadian Covid-19 serta kepadatan penduduk di Kabupaten Magelang. Lokasi penelitian dapat di lihat pada gambar 1.

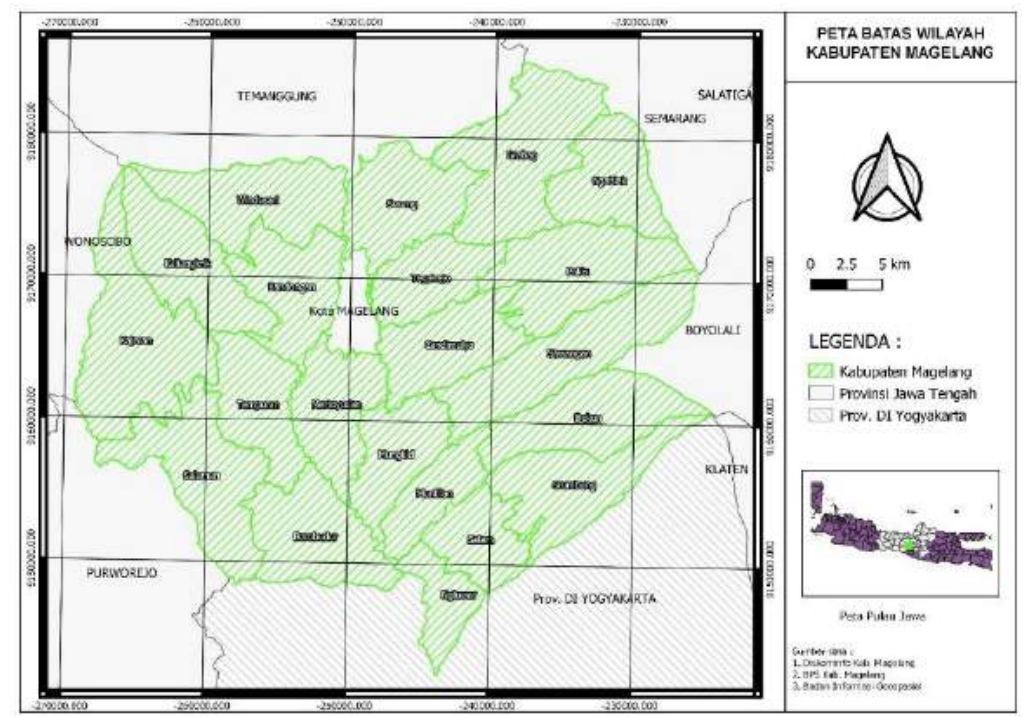

Gambar 1. Peta Batas Wilayah Kabupaten Magelang

HASIL PENELITIAN

Hubungan Variabel Kepadatan Penduduk Dengan Kasus Mingguan COVID-19 Di Kabupaten Magelang

Data kepadatan penduduk berdasarkan kecamatan di Kabupaten Magelang dan kasus Covid-19 pada Bulan Desember 2021 tersaji dalam tabel 1 di bawah ini : 
Tabel 1. Distribusi kejadian Covid-19 Bulan Desember 2020

\begin{tabular}{clcccc}
\hline No. & Kecamatan & $\begin{array}{c}\text { Total } \\
\text { Kasus }\end{array}$ & $\begin{array}{c}\text { Rata2 } \\
\text { Perminggu }\end{array}$ & $\begin{array}{c}\text { Rata-rata } \\
\text { Perminggu } \\
\text { Kabupaten }\end{array}$ & $\begin{array}{c}\text { Kepadatan } \\
\text { penduduk } \\
\text { jiwa/km }{ }^{2}\end{array}$ \\
\hline 1 & Bandongan & 161 & 32,2 & 30,01 & 1335 \\
\hline 2 & Borobudur & 264 & 52,8 & 30,01 & 1140 \\
\hline 3 & Candimulyo & 92 & 18,4 & 30,01 & 1061 \\
\hline 4 & Dukun & 71 & 14,2 & 30,01 & 872 \\
\hline 5 & Grabag & 148 & 29,6 & 30,01 & 1201 \\
\hline 6 & Kajoran & 85 & 17 & 30,01 & 712 \\
\hline 7 & Kaliangkrik & 52 & 10,4 & 30,01 & 1037 \\
\hline 8 & Mertoyudan & 517 & 103,4 & 30,01 & 2554 \\
\hline 9 & Mungkid & 250 & 50 & 30,01 & 1998 \\
\hline 10 & Muntilan & 212 & 42,4 & 30,01 & 2794 \\
\hline 11 & Ngablak & 56 & 11,2 & 30,01 & 953 \\
\hline 12 & Ngluwar & 69 & 13,8 & 30,01 & 1444 \\
\hline 13 & Pakis & 60 & 12 & 30,01 & 786 \\
\hline 14 & Salam & 120 & 24 & 30,01 & 1520 \\
\hline 15 & Salaman & 122 & 24,4 & 30,01 & 1074 \\
\hline 16 & Sawangan & 102 & 20,4 & 30,01 & 797 \\
\hline 17 & Secang & 268 & 53,6 & 30,01 & 1743 \\
\hline 18 & Srumbung & 117 & 23,4 & 30,01 & 910 \\
\hline 19 & Tegalrejo & 153 & 30,6 & 30,01 & 1534 \\
\hline 20 & Tempuran & 155 & 31 & 30,01 & 1061 \\
\hline 21 & Windusari & 77 & 15,4 & 30,01 & 838 \\
\hline & & & & & \\
\hline & & & & & \\
\hline 12 & & & & \\
\hline
\end{tabular}

Pada bulan Desember tahun 2020, terjadi 3151 kejadian Covid-19 atau kasus terkomfirmasi positif di Kabupaten Magelang dengan rata-rata 30,01 kasus perminggu di setiap kecamatannya. Dari data tersebut dapat terlihat bahwa kepadatan penduduk di Kabupaten Magelang berbeda-beda antar kecamatan dengan Kecamatan Muntilan memiliki angka kepadatan penduduk tertinggi yaitu 2794 jiwa per $\mathrm{km}^{2}$ di banding kecamatan lain, sedangkan Kecamatan Kajoran adalah kecamatan dengan kepadatan terendah yaitu 712 Jiwa per km². Rata-rata Angka kejadian kasus mingguan menunjukkan bahwa 8 Kecamatan berada di atas rata-rata kejadian mingguan Kabupaten yaitu Kecamatan Bandongan, Borobudur, Mertoyudan, Mungkid, Muntilan, Secang, Tegalrejo, dan Tempuran. Berdasarkan data tersebut terlihat Bahwa terdapat 7 kecamatan yang memiliki kepadatan penduduk diatas rata-rata kepadatan penduduk Kabupaten Magelang yaitu Kecamatan Bandongan, Mertoyudan, Mungkid, Muntilan, Ngluwar, Salam, dan Secang. Hasil diatas selanjutnya akan di sajikan dalam bentuk peta dengan menampilkan data kejadian Covid-19 perminggunya seperti gambar 2 di bawah ini : 


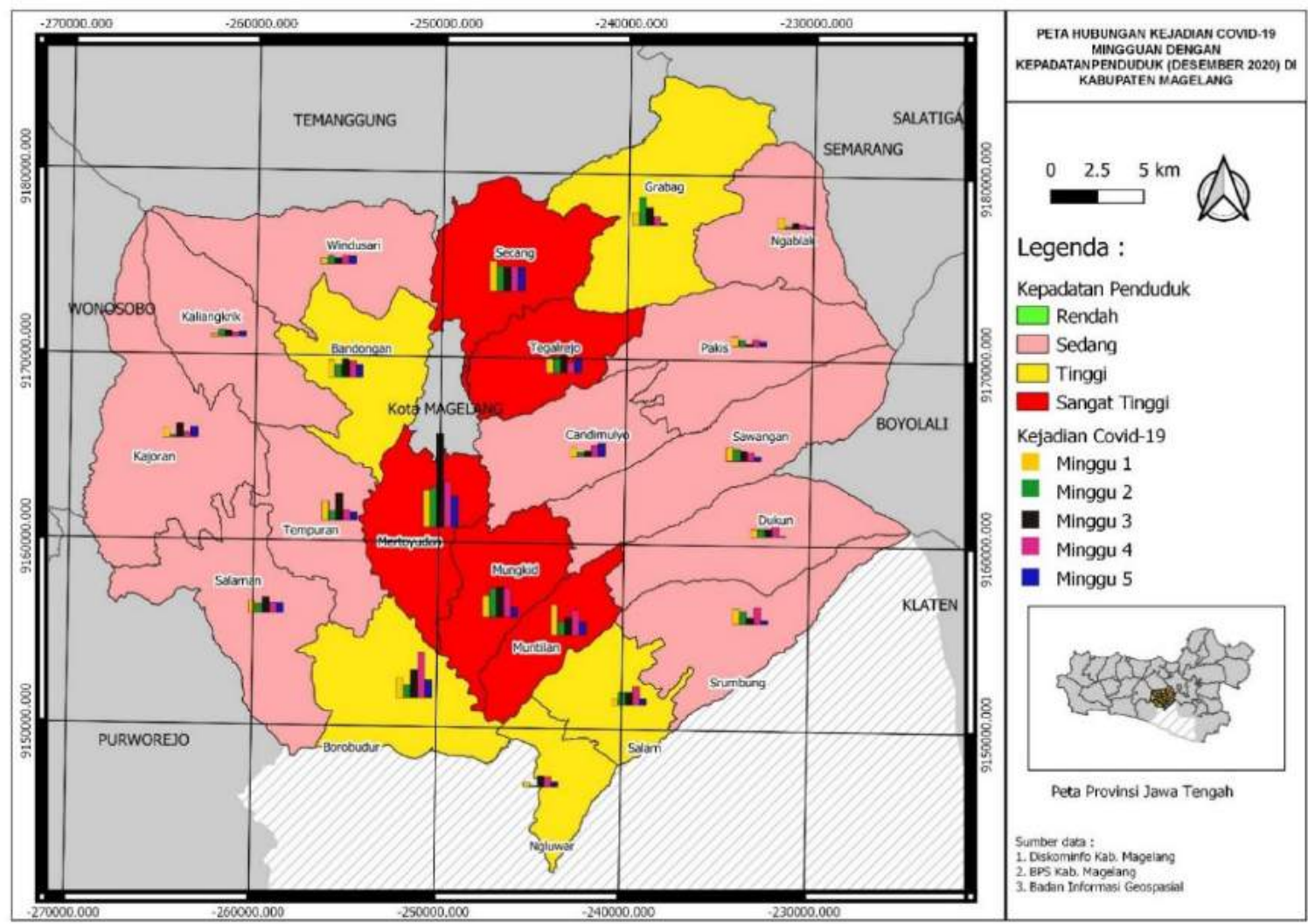

Gambar 2. Peta kepadatan penduduk dan histogram kejadian Covid-19 per Minggu di Kabupaten Magelang Provinsi Jawa Tengah

\section{PEMBAHASAN}

\section{Hubungan Variabel Kepadatan Penduduk Dengan Kejadian Covid-19 Di Kabupaten Magelang}

Hubungan kedua variabel menunjukkan arah yang sama dimana bila variabel kepadatan penduduk semakin tinggi maka variabel kejadian Covid-19 semakin tinggi. Hasil analisis statistik dengan regresi linear menunjukkan pengaruh yang kuat diantara kedua variabel tersebut dimana nilai $R$ Square adalah 0,549 yang dapat diartikan bahwa 54,9 \% jumlah Kejadian Covid-19 bulan Desember tahun 2020 di Kabupaten Magelang di pengaruhi oleh kepadatan penduduk, dengan kata lain masih terdapat $46 \%$ faktor lain yang dapat mempengaruhi. Berdasarkan hasil analisis statistik tersebut dapat di katakan bahwa peningkatan kejadian Covid-19 seiring dengan kepadatan penduduk pada masing-masing wilayah kecamatan di Kabupaten Magelang pada bulan Desember tahun 2020. Dimana Kecamatan Muntilan dan Kecamatan Mertoyudan yang memiliki nilai kepadatan penduduk tertinggi di Kabupaten Magelang mengalami tingkat kenaikan kasus yang cukup signifikan yaitu 212 penambahan kasus baru untuk Kecamatan Muntilan dan 517 penambahan kasus baru untuk Kecamatan Mertoyudan dimana kedua kecamatan tersebut memiliki angka kepadatan penduduk diatas $2500 \mathrm{jiwa} / \mathrm{km}^{2}$. 
Untuk kecamatan lainnya berada pada tingkat penambahan kasus sedang sampai rendah di bulan tersebut. Sementara data lain menunjukkan untuk kecamatan yang memiliki kepadatan penduduk diantara $700 \mathrm{jiwa} / \mathrm{km}^{2}$ sampai dengan $1500 \mathrm{jiwa} / \mathrm{km}^{2}$ mengalami penambahan kasus yang cenderung rendah dan sedang yaitu pada kisaran 60 kasus sampai dengan 153 kasus pada Bulan Desember 2020. Kondisi tersebut sesuai dengan penelitian yang dilakukan di Kabupaten Banjarnegara yang menjelaskan bahwa kepadatan penduduk memiliki hubungan yang erat dengan kenaikan kasus di wilayah tersebut ${ }^{14}$. Penelitian lainnya di Aljazair menjelaskan tentang terdapatnya korelasi yang kuat antara kepadatan penduduk dengan jumlah infeksi Covid-19 di Aljazair ${ }^{15}$, korelasi positif tersebut menunjukkan perlunya upaya pembatasan sosial pada daerah dan kluster dengan kepadatan penduduk yang tinggi karena kepadatan penduduk menjadi salah satu indikator perlunya di lakukan lockdown pada area tersebut ${ }^{16}$. Selain itu kondisi tersebut dimungkinkan karena kepadatan penduduk yang tinggi cenderung akan memicu semakin tingginya aktifitas masyarakat di wilayah tersebut, seperti pada penelitian yang dilakukan di kabupaten Tegal dan Kota Semarang ${ }^{14}$. Wilayah Kecamatan Mertoyudan dan Kecamatan Muntilan lokasinya berada pada ruas jalur padat aktifitas karena wilayah tersebut berada pada jalur antara Provinsi Jawa Tengah dan Provinsi DI Yogyakarta.

\section{Pemetaan kejadian Mingguan Covid-19}

Analisis spasial kejadian Covid-19 pada tingkat mingguan di wilayah kecamatan pada Kabupaten Magelang di sajikan pada Gambar 2. Berdasarkan peta tersebut terlihat bahwa kecamatan tertinggi untuk kejadian kasus pada Bulan Desember 2020 adalah Kecamatan Mertoyudan dengan 517 kasus(16\%), Secang dengan 268 kasus(9\%), dan Borobudur dengan 264 kasus (8\%) sedangkan kejadian terendah adalah Kecamatan Kaliangkrik dengan 52 kasus (2\%). Sementara untuk kasus mingguan kasus tertinggi di Kabupaten Magelang terjadi pada minggu ke 2 Bulan Desember 2020 yaitu tanggal 13-19 Desember dengan 790 penambahan kasus baru terkonfirmasi positif Covid-19. Pada minggu ketiga tersebut Kecamatan Mertoyudan adalah kecamatan dengan kasus tertinggi yaitu 196 penambahan kasus baru, disusul Kecamatan Mungkid (63 kasus) dan Kecamatan Borobudu (59 kasus). Peningkatan kasus yang begitu tinggi di minggu ketiga bulan Desember tersebut terjadi mengingat mobilitas masyarakat di minggu tersebut meningkat di karenakan menjelang libur hari besar di akhir Desember 2020. Sesuai dengan penelitian yang dilakukan di China bahwa pembatasan yang jelas menjelang hari libur nasional akam membantu menghentikan laju kasus baru sampai 7,54 hari ${ }^{17}$. Penelitian sejenis di Pulau Kreta Yunani yang menjelaskan bahwa wilayah yang menjadi tujuan liburan akan memiliki potensi penularan lebih tinggi dibanding wilayah lain yang tidak memiliki tujuan wisata mengingat perilaku bepergian wisatawan yang masih tinggi ${ }^{18}$. 
Selain hal tersebut bila merujuk pada peta yang telah di sajikan terlihat bahwa posisi ketiga kecamatan dengan kepadatan tinggi tersebut adalah kecamatan berada pada lokasi dengan potensi akses dan aktifitas tinggi di masyarakat dimana Kecamatan Mertoyudan dan Mungkid adalah kecamatan yang berada di antara Kabupaten Semarang Provinsi Jawa Tengah dan Kabupaten Sleman Provinsi DI Yogyakarta, Sementara Kecamatan Borobudur adalah salah satu kecamatan yang memiliki obyek wisata populer di Jawa Tengah sehingga kondisi tersebut berpotensi menjadi lokasi dengan aktifitas pergerakan masyarakat yang tinggi.

Hasil pemetaan tersebut juga menunjukkan bahwa Kecamatan Mertoyudan adalah kecamatan dengan angka penyebaran terbesar dalam bulan Desember 2020 yaitu 517 penambahan kasus baru. Dimana terjadi lonjakan kasus pada minggu ketiga (13-19 desember) yaitu 196 kasus baru setelah sebelumnya pada minggu ke 2 (6-12 Desember) dan ke 1(1-5 Desember) terdapat penambahan kasus 78 dan 83 kasus baru dan menurun kembali pada minggu ke 4(20-26 Desember) yaitu 95 kasus dan minggu ke 5 (27-31 Desember) yaitu 65 kasus baru. Kecamatan Mertoyudan termasuk kedalam wilayah perkotaan di Kabupaten Magelang. Pemanfaatan waktu libur akhir tahun oleh warganya dan wilayah kecamatan yang termasuk kedalam jalur antar provinsi menjadi salah satu potensi penyumbang peningkatan kasus di kecamatan tersebut. Lonjakan kasus yang terjadi di kecamatan ini dapat di akibatkan oleh transmisi impor dari warga yang mengunjungi Kecamatan Mertoyudan yang dapat berasal dari warga yang memanfaatkan libur dan menetap di kecamatan tersebut ataupun yang melakukan perjalanan dengan tujuan utama bukan Kecamatan Mertoyudan.

Kecamatan Secang, Muntilan, dan Mungkid adalah kecamatan dengan kepadatan penduduk diatas $1500 \mathrm{jiwa} / \mathrm{km}^{2}$, keempatnya cenderung mengalami penambahan kasus baru yang konstan selama 5 minggu di bulan Desember 2020 yaitu pada range antara 20 sampai dengan 65 kasus baru perminggu, namun demikian angka tersebut adalah angka penambahan kasus relatif tinggi di banding kecamatan lainnya. Posisi ke empat kecamatan yang berada di lintas jalur antar provinsi kemungkinan menjadi penyebab kenaikan kasus tersebut, dimana aktifitas di wilayah tersebut cenderung meningkat pada masa libur nasional akhir tahun. Kecamatan Borobudur memiliki pola spasial penularan kasus yang fluktuatif karena pada minggu pertama, kedua dan ketiga cenderung konnstan namun di minggu ke empat terjadi lonjakan kasus hingga 96 kasus baru (20-26 Desember), kondisi tersebut dikarenakan Kecamatan Borobudur adalah Kecamatan dengan jumlah obyek wisata terbanyak di Kabupaten Magelang, walaupun pemerintah kabupaten sudah membatasi aktifitas wisata ada kemungkinan wisatawan tetap berkunjung ke wilayah tersebut.

Kecamatan Pakis, Ngablak dan Kaliangkrik adalah kecamatan dengan penambahan kasus terendah selama bulan Desember 2020 yaitu 60, 56 dan 52 kasus baru, dari ketiga 
kecamatan tersebut hanya Kecamatan Kaliangkrik yang memiliki kepadatan penduduk di atas $1000 \mathrm{jiwa} / \mathrm{km}^{2}$, yaitu $1037 \mathrm{jiwa} / \mathrm{km}^{2}$ sedangkan Kecamatan Pakis dan Ngablak memiliki kepadatan penduduk $786 \mathrm{jiwa} / \mathrm{km}^{2}$ dan $953 \mathrm{jiwa} / \mathrm{km}^{2}$. Untuk wilayah dengan kepadatan penduduk sedang sampai rendah cenderung memiliki kegiatan dan aktifitas yang rendah sehingga akan mengurangi risiko penularan penyakit dengan penyakit yang berbasis lingkungan ${ }^{19}$.

\section{SIMPULAN DAN SARAN}

Berdasarkan hasil penelitian tersebut dapat di tarik kesimpulan bahwa persebaran kasus Covid-19 mingguan di Kabupaten Magelang dipengaruhi oleh tingkat kepadatan penduduk yang berada di wilayah kecamatan tersebut mengingat terdapat dua kecamatan dengan kasus tertinggi yang merupakan kecamatan dengan kepadatan penduduk yang tinggi. Dari hasil pemetaan spasial yang dilakukan pada minggu ketiga tersebut sebaran kasus tertinggi terdapat di Kecamatan Mertoyudan dan Kecamatan Mungkid yang memiliki kepadatan penduduk diatas 1900 jiwa/km2.

Di sarankan kepada masyrakat dan pemerintah daerah selaku pemangku kepentingan agar dapat memberikan perhatian kepada wilayah dengan tingkat kepadatan penduduk tinggi dalam upaya pencegahan dan pengendalian penyebaran Covid-19 di Kabupaten Magelang seperti mensosialisasikan protokol kesehatan 5M yaitu Mencuci tangan, menjaga jarak, menjauhi kerumunan, menggunakan masker dan mengurangi mobiltas).

\section{DAFTAR PUSTAKA}

1. WHO. Modes of transmission of virus causing COVID-19: implications for IPC precaution recommendations. Geneva World Heal Organ [Internet]. 2020;Available(March):19-21. Available from: https://www.who.int/publicationsdetail/modes-of-transmission-of-virus-causing-covid-19-implications-for-ipc-precautionrecommendations

2. Yuliana Y. Corona virus diseases (Covid-19): Sebuah tinjauan literatur. Wellness Heal Mag. 2020;2(1):187-92.

3. Munster VJ, Koopmans M, van Doremalen N, van Riel D, de Wit E. A novel coronavirus emerging in China-key questions for impact assessment. $N$ Engl $J$ Med. 2020;382(8):692-4.

4. WHO. WHO Coronavirus (COVID-19) Dashboard [Internet]. WHO Homepage. 2021. Available from: https://covid19.who.int/?gclid=EAlalQobChMI3aKy0_f07gIVT3mLCh3YvAZWEAAYASA AEgLhufD_BwE

5. KPCPEN. Data Sebaran [Internet]. Satuan Tugas Penanganan COVID-19. 2021. p. 1. 
Available from: https://covid19.go.id/

6. Huang R, Liu M, Ding Y. Spatial-temporal distribution of COVID-19 in China and its prediction: A data-driven modeling analysis. J Infect Dev Ctries. 2020;14(03):246-53.

7. Yusrina FN, Sari MI, Pratiwi GCAH, Hidayat DW, Jordan E, Febriyanti D. Analisis Pola Permukiman Menggunakan Pendekatan Nearest Neighbour Untuk Kajian Manfaat Objek Wisata Di Kecamatan Prambanan Kabupaten Klaten. J Geogr Edukasi dan Lingkung. 2018;2(2):111-20.

8. Huang Q, Jackson S, Derakhshan S, Lee L, Pham E, Jackson A, et al. Urban-rural differences in COVID-19 exposures and outcomes in the South: A preliminary analysis of South Carolina. PLoS One. 2021;16(2):e0246548.

9. Nelwan JE. Kejadian Corona Virus Disease 2019 berdasarkan Kepadatan Penduduk dan Ketinggian Tempat per Wilayah Kecamatan. J Public Heal Community Med. 2020;1(April):32-45.

10. Ardiansyah R. Analisis Spasial Tingkat Mobilitas Penduduk, kepadatan Penduduk Dan Faktor Lingkungan Dengan Kejadian Covid-19 di Kota Semarang. Diponegoro University; 2021.

11. Wahyuni DN. Pengaruh Kepadatan Penduduk Terhadap Jumlah Kasus Mingguan Covid-19 Di Kabupaten Badung Provinsi Bali. J Geogr Edukasi Dan Lingkung. 2021;5(1):46-51.

12. Pourghasemi HR, Pouyan S, Farajzadeh Z, Sadhasivam N, Heidari B, Babaei S, et al. Assessment of the outbreak risk, mapping and infection behavior of COVID-19: Application of the autoregressive integrated-moving average (ARIMA) and polynomial models. PLoS One. 2020;15(7):e0236238.

13. BPS Kabupaten Magelang. Kabupaten Magelang Dalam Angka tahun 2021 [Internet]. Kabupaten Magelang; 2021. Available from: https://magelangkab.bps.go.id/

14. KRISDIYAWATI K. ANALISIS SPASIAL FAKTOR IKLIM, KEPADATAN DAN MOBILITAS PENDUDUK YANG BERHUBUNGAN DENGAN SEBARAN KASUS COVID-19 (Studi di Wilayah Kabupaten Banjarnegara, Kabupaten Cilacap, Kabupaten Tegal dan Kota Semarang Tahun 2020). Diponegoro University; 2021.

15. Kadi N, Khelfaoui M. Population density, a factor in the spread of COVID-19 in Algeria: statistic study. Bull Natl Res Cent. 2020;44(1):1-7.

16. Sun Z, Zhang H, Yang $\mathrm{Y}$, Wan $\mathrm{H}$, Wang $\mathrm{Y}$. Impacts of geographic factors and population density on the COVID-19 spreading under the lockdown policies of China. Sci Total Environ. 2020;746:141347.

17. Chen S, Chen Q, Yang W, Xue L, Liu Y, Yang J, et al. Buying time for an effective epidemic response: the impact of a public holiday for outbreak control on COVID-19 epidemic spread. Engineering. 2020;6(10):1108-14. 
18. Kourgiantakis M, Apostolakis A, Dimou I. COVID-19 and holiday intentions: the case of Crete, Greece. Anatolia. 2021;32(1):148-51.

19. Achmadi UF. Dasar dasar Penyakit Berbasis Wilayah. Rajawali Press. Jakarta: Rajawali Press; 2013. 